\title{
Cytokine Induced Killer cells effectively kill chemo-resistant melanoma cancer stem cells
}

\author{
Loretta Gammaitoni ${ }^{1}$, Lidia Giraudo ${ }^{1,2^{*}}$, Valeria Leuci ${ }^{1}$, Giulia Mesiano ${ }^{1}$, Michela Cangemi $^{2}$, Alessandro Zaccagna ${ }^{1}$, \\ Alberto Pisacane ${ }^{1}$, Susanna Gallo², Fabrizio Carnevale-Schianca', Massimo Aglietta ${ }^{1,2}$, Dario Sangiolo ${ }^{1,2}$ \\ From Melanoma Bridge Meeting 2014 \\ Naples, Italy. 03-06 December 2014
}

\section{Background}

Metastatic Melanoma (mMel) is considered refractory to conventional chemotherapies. New molecular targeted approaches, inhibiting mutated forms of the serinethreonine kinase B-RAF, significantly increased the response rate but patients almost invariably relapse and prognosis remains severe $[1,2]$. Open challenge is the characterization and targeting of cancer stem cells (CSCs), considered responsible for chemoresistance and disease relapse. Adoptive immunotherapy holds great promises for the treatment of $\mathrm{mMel}$ and research efforts are ongoing to explore its potential activity against melanoma CSCs (mCSCs). Cytokine Induced Killer (CIK) cells are a subset of ex vivo expanded T lymphocytes with mixed $\mathrm{CD}^{+}{ }^{+} \mathrm{CD} 56^{+}$phenotype and endowed with HLA-unrestricted tumor killing activity. We and others recently reported the preclinical activity of CIK cells against several solid tumors including mMel [3].

Aim of our research is to explore the preclinical activity of CIK cells against autologous $\mathrm{mCSCs}$ surviving treatments with chemo or molecular targeted therapies.

\section{Material and methods}

We set a preclinical autologous immunotherapy model with primary melanoma cultures and CIK cells generated from patients treated at our Center. To visualize mCSCs we transduced tumor cells with a lentiviral CSC-detector vector encoding enhanced Green Fluorescent Protein (eGFP) under control of the stem-gene oct4 promoter. We treated all mMel cultures with chemotherapy drug fotemustine (IC50 dose). Melanoma cultures harboring BRAF V600E mutations were also treated with BRAF inhibitor (BRAFi) dabrafenib (IC50 dose). We evaluated

${ }^{1}$ Candiolo Cancer Institute - IRCCS, Candiolo, Italy

Full list of author information is available at the end of the article the presence of residual mCSCs among mMel cells surviving $72 \mathrm{~h}$ of treatment and explored their susceptibility to immunotherapy with autologous CIK cells.

\section{Results}

We visualized mCSCs within $11 \mathrm{mMel}$ cultures $(3 / 11$ BRAF V600E mutated); median value of eGFP + mCSCs was $15 \%$ (range $3.5-26.4 \%$ ). Putative mCSCs displayed a relative resistance to conventional treatments. The presence of eGFP + mCSCs increased of $39 \%$ and $25 \%$ among melanoma cells that survived exposure to fotemustine and BRAFi respectively, compared to untreated controls $(n=11)$. CIK cells effectively killed autologous mMel and mCSCs. Tumor specific killing, equally involving bulk mMel targets and $\mathrm{mCSCs}$, ranged between $75 \%$ and $33 \%$ at effector target ratios of $40: 1$ and $1: 1$ respectively $(\mathrm{n}=8)$.

\section{Conclusion}

We provided first proof of concept that putative mCSCs are relatively resistant to conventional treatments with chemo or molecular targeted therapy and susceptible to immunotherapy killing by autologous CIK cells. These preclinical findings support the hypothesis that mCSC may be responsible for disease relapses and support designing of experimental immunotherapy clinical trials with CIK cells in mMel settings.

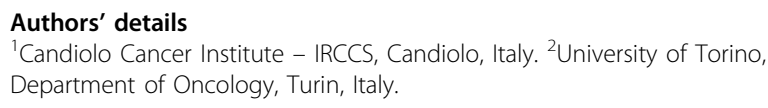

Published: 15 January 2015

\section{References}

1. Chapman PB, Hauschild A, Robert C, Haanen JB, Ascierto P, Larkin J, Dummer R, Garbe C, Testori A, Maio M, Hogg D, Lorigan P, Lebbe C, 
Jouary T, Schadendorf D, Ribas A, O'Day SJ, Sosman JA, Kirkwood JM, Eggermont AM, Dreno B, Nolop K, Li J, Nelson B, Hou J, Lee RJ, Flaherty KT, McArthur GA, BRIM-3 Study Group: Improved survival with vemurafenib in melanoma with BRAF V600E mutation. N Engl I Med 2011, 364(26):2507-2516

2. Flaherty KT, Infante JR, Daud A, Gonzalez R, Kefford RF, Sosman J, Hamid O, Schuchter L, Cebon J, Ibrahim N, Kudchadkar R, Burris HA 3rd, Falchook G Algazi A, Lewis K, Long GV, Puzanov I, Lebowitz P, Singh A, Little S, Sun P, Allred A, Ouellet D, Kim KB, Patel K, Weber J: Combined BRAF and MEK inhibition in melanoma with BRAF V600 mutations. N Engl J Med 2012, 367(18):1694-1703.

3. Gammaitoni L, Giraudo L, Leuci V, Todorovic M, Mesiano G, Picciotto F, Pisacane A, Zaccagna A, Volpe MG, Gallo S, Caravelli D, Giacone E, Venesio T, Balsamo A, Pignochino Y, Grignani G, Carnevale-Schianca F, Aglietta M, Sangiolo D: Effective activity of cytokine-induced killer cells against autologous metastatic melanoma including cells with stemness features. Clin Cancer Res 2013, 19(16):4347-4358.

doi:10.1186/1479-5876-13-S1-01

Cite this article as: Gammaitoni et al:: Cytokine Induced Killer cells effectively kill chemo-resistant melanoma cancer stem cells. Journal of Translational Medicine 2015 13(Suppl 1):01.

\section{Submit your next manuscript to BioMed Central and take full advantage of:}

- Convenient online submission

- Thorough peer review

- No space constraints or color figure charges

- Immediate publication on acceptance

- Inclusion in PubMed, CAS, Scopus and Google Scholar

- Research which is freely available for redistribution

Submit your manuscript at www.biomedcentral.com/submit 